\title{
Occurrence and Distribution of Volatile Organic Compounds in Drinking Water Supplied by Community Water Systems in the Northeast and Mid-Atlantic Regions of the United States, 1993-98
}

—Michael Moran, Stephen Grady, and John Zogorski

Data on volatile organic compounds (VOCs) in drinking water supplied by community water systems (CWSs) are available for 12 Northeast and MidAtlantic States from 1993-98. The data are from 2,110 CWSs representing a 20 percent random selection of the total 10,749 active CWSs in the region. The data were collected for compliance monitoring under the Safe Drinking Water Act from both surface- and ground-water sources and largely represent samples of finished drinking water collected prior to distribution. Overall, 39 percent of the 2,110 randomly selected CWSs reported a detection of one or more VOCs at or above $1.0 \mu \mathrm{g} / \mathrm{L}$ (micrograms per liter).

Although differences in analytical coverage complicate comparisons, in the 1,543 CWSs with THM data at or above $1.0 \mu \mathrm{g} / \mathrm{L}, 42$ percent reported an occurrence of one or more THMs. The common detection of THMs in finished drinking water probably is related to their formation through the chlorination of drinking-water supplies. Comparatively, solvents, the next most frequently detected VOC group, were reported in 9.8 percent of 2,097 CWSs with solvent data at or above $1.0 \mu \mathrm{g} / \mathrm{L}$, and gasoline components were detected in 9.0 percent of 2,098 CWSs with data at or above $1.0 \mu \mathrm{g} / \mathrm{L}$.

Individually, the THMs-chloroform, bromodichloromethane, chlorodibromomethane, and bromoform-were the most frequently detected VOCs ranging from 33 to 8 percent. The most frequently detected non-THM compound was methyl tert-butyl ether, which was identified in 8 percent of CWSs. Of the 2,110 randomly selected CWSs, 6 percent had at least one sample with one or more VOCs with a concentration above a Maximum Contaminant Level, Health Advisory, or Drinking-Water Advisory.
VOCs were more frequently detected in drinking water from systems that are supplied by surface-water sources, or both surface- and ground-water sources, than in systems that are supplied exclusively by ground water, and from systems serving very large and large populations (serving $>3,300$ people) compared to systems serving medium and small populations (serving $\leq 3,300$ people).

\section{Introduction}

Identifying and understanding the occurrence of volatile organic compounds (VOCs) in drinking water is important. Contamination of drinkingwater supplies by VOCs is a human health concern because many are toxic or are known or suspected human carcinogens (U.S. Environmental Protection Agency, 2000). The occurrence of VOCs in surface- and ground-water resources is widespread (Delzer and others, 1996; Lopes and Dionne, 1998; Squillace and others, 1999; Lopes and others, 2000) and the occurrence of VOCs in public drinking water has been noted for some time (Westrick and others, 1984). In a recent national survey of community water systems (CWSs), 38 percent of CWSs identified VOCs as potential contaminants in their source waters (U.S. Environmental Protection Agency, 1997). In that same survey, 23 percent of CWSs with exclusively surface-water sources and 27 percent of CWSs with exclusively ground-water sources indicated that they used some type of treatment in at least one facility to remove organic contaminants (U.S. Environmental Protection Agency, 1997).

Under the Safe Drinking Water Act (SDWA), the U.S. Environmental Protection Agency (USEPA) has established Maximum Contaminant Levels
(MCLs) for 21 VOCs in drinking water supplied by CWSs. Drinking water supplied by CWSs is required to be monitored for compounds with MCLs. The data from the compliance monitoring of CWSs provide an important resource of information on the occurrence and distribution of both regulated and unregulated VOCs in drinking water from surfaceand ground-water sources.

The primary purpose of this fact sheet is to describe the occurrence and distribution of VOCs in public drinking water. To achieve this, the U.S. Geological Survey (USGS), in cooperation with the USEPA, Office of Ground Water and Drinking Water, conducted an assessment of the quality of drinking water from CWSs in 12 Northeast and MidAtlantic States. The Northeast and MidAtlantic regions were selected for this study because they are generally highly populated, have a long-term history of urbanization, and are areas with high use of public water supply. The samples were collected during 1993-98 to meet the requirements of the SDWA and primarily represent finished drinking water collected prior to distribution. Information provided here on the occurrence and distribution of VOCs in drinking water within the study area summarizes a more comprehensive report by Grady and Casey (2001).

\section{Design Approach and Data Set}

The number, size, source, and location (by State) of CWSs selected for this study represented the actual distribution of CWSs in the region. A stratified random design was chosen to select the systems to be included in the data inventory, review, and analysis (Grady and Casey, 1999). This design allowed for a statistical comparison of data by State, 
source of water, and number of people served by the utility. As of December 1, 1997, a total of 10,749 CWSs provided drinking water to more than 58 million people in the 12 Northeast and MidAtlantic States. Of these CWSs, 2,110, or about 20 percent, were randomly selected for this study. The stratified random design distributed the CWSs among the 12 States in direct proportion to their actual distribution with respect to the number and size of the systems, and source of water.

Screening data from State health and water-supply agencies for the 2,110 selected CWSs resulted in more than 21,000 VOC analyses available for this assessment. The locations of 5,022 surface- and ground-water sources for the 2,110 selected CWSs are shown in figure 1. Identification of the sources and their locations were obtained from a variety of State and Federal data bases. Although not every source for every system could be spatially located, the distribution shown in figure 1 includes the majority of sources and accurately reflects the spatial distribution of sources.

The number of compounds analyzed varied from State to State and thus the number of analyses for each compound varied similarly. Chemical analyses for 21 VOCs regulated under the SDWA and 21 unregulated VOCs are determined routinely for most drinking water samples and an additional 14 VOCs may be included at the discretion of the individual States. In the overall data set, information for 84 individual VOCs was reported. The laboratory minimum reporting level for VOCs was variable among the different State and private laboratories that performed the analyses. For most VOCs the laboratory minimum reporting level was about $0.5 \mu \mathrm{g} / \mathrm{L}$ (micrograms per liter).

\section{Occurrence and Distribution}

Chemical data were censored to a level of $1.0 \mu \mathrm{g} / \mathrm{L}$ to determine detection frequency for any VOC, groups of VOCs, and individual VOCs. This strategy helped to equalize variability in laboratory minimum reporting levels and allowed for the most direct comparison of detection frequencies among groups of VOCs, and among individual VOCs.

\section{Occurrence of VOCs by Group}

For purposes of comparison, individual VOCs were grouped into categories generally reflecting the predominant use of the compounds. The five groups based on predominant use are:

(1) solvents, (2) gasoline components, (3) refrigerants, (4) fumigants, and (5) VOCs used in the synthesis of other chemicals. Another group also was included-trihalomethanes (THM) including chloroform, bromodichloromethane, chlorodibromomethane, and bromoform. Although the name of this group does not reflect a predominant use of the chemicals, THMs commonly are detected in finished drinking water. THMs are known to form in water as a result of reactions between disinfection agents and organic matter in the water. For CWSs that have some or all of their water supplied by surface-water sources, the frequent occurrence of THMs in treated water may be attributed to reactions between disinfection agents and organic matter in the water. The fuel oxygenate methyl tert-butyl ether (MTBE) was included in the gasoline components group. MTBE has recently emerged as a contaminant of concern that is commonly found at low concentrations in surface and ground water (Zogorski and others, 1998; Moran and others, 1999) and now must be monitored in some CWSs as an unregulated contaminant (U.S. Environmental Protection Agency, 1999).

Of the 2,110 randomly selected CWSs, 39 percent had a detection of one or more VOCs at or above $1.0 \mu \mathrm{g} / \mathrm{L}$. The distribution of surface- and ground-water sources from CWSs with and without a detection of any VOC is shown in figure 1 . The sources indicated as having a detection of any VOC in figure 1 include all of the sources for a system with a detection and do not indicate the specific source that had the detection.

The THMs were by far the most commonly occurring VOC group and were detected in 42 percent of the 1,543 CWSs with data (table 1). The common detection of THMs in finished drinking water probably is related to their formation through the chlorination of drinkingwater supplies. Chlorination of drinking-water supplies for disinfection has been known to result in the formation of THMs through reactions with

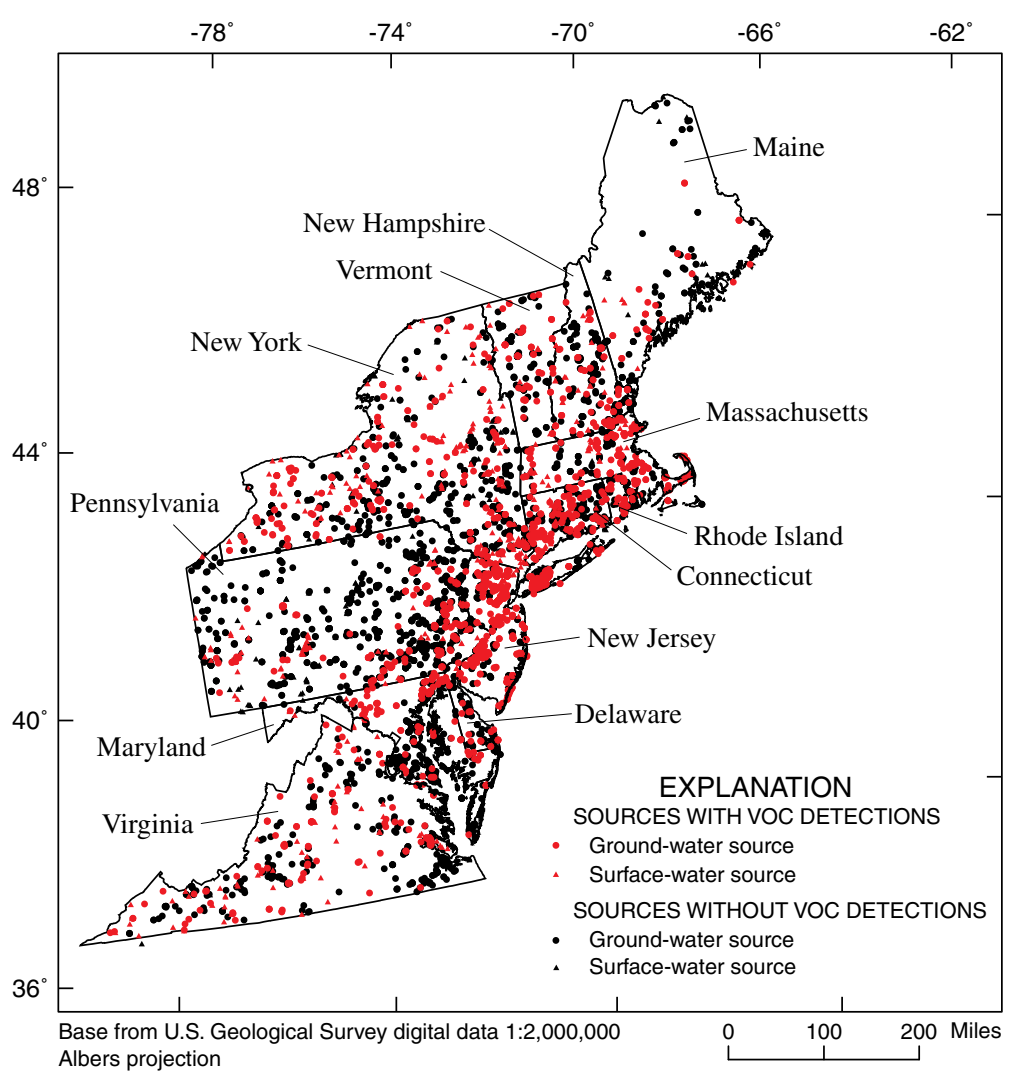

Figure 1. Drinking-water sources for randomly selected community water systems in the study area, showing sources with analytical data and sources with reported detectable concentrations of any volatile organic compound (VOC) in any source in the system at or above 1.0 microgram per liter. 
naturally occurring organic material in the water. Solvents were detected in 9.8 percent of CWSs, and gasoline components were detected in 9.0 percent of CWSs. The pattern of detection of VOCs by group was statistically significant at the 95-percent confidence interval $(p<0.0001)$. In general, VOCs in groups that are more widely used, such as solvents and gasoline components, were detected more frequently than VOCs in groups that are not as widely used, such as organic synthesis compounds, refrigerants, and fumigants (table 1).

\section{Occurrence of Individual VOCs}

Of the 84 individual VOCs analyzed, 54 were detected in at least one sample at or above $1.0 \mu \mathrm{g} / \mathrm{L}$. Detection frequencies for the 20 individual VOCs that were reported in more than 1 percent of CWSs are shown in figure 2. Individually, the four THMs - chloroform, bromodichloromethane, chlorodibromomethane, and bromoform-were the most frequently detected VOCs, ranging from 33 to 8 percent. When the concentrations of the four THMs were summed, the resultant total THMs were detected in 42 percent of the CWSs with data. The most frequently detected non-THM compound was MTBE, which was identified in 8 percent of CWSs. The frequency of MTBE detections in drinking water is significantly related to high

Table 1. Number of systems with analyses of one or more compounds in groups of volatile organic compounds, number of systems with a detection of one or more compounds in groups of volatile organic compounds at or above 1.0 micrograms per liter, and frequency of detection of groups of volatile organic compounds in drinking water from randomly selected community water systems in the study area

[VOCs, volatile organic compounds; $\mu \mathrm{g} / \mathrm{L}$, micrograms per liter]

\begin{tabular}{lccc}
\hline \multicolumn{1}{c}{ voc group } & $\begin{array}{c}\text { Number of systems with } \\
\text { analyses of one or more } \\
\text { VOCs in group }\end{array}$ & $\begin{array}{c}\text { Number of systems with } \\
\text { detection of one or more } \\
\text { VOCs in group at 1.0 } \mathbf{\mu g} / \mathbf{L}\end{array}$ & $\begin{array}{c}\text { Frequency } \\
\text { of } \\
\text { detection }\end{array}$ \\
\hline Trihalomethanes & 1,543 & 644 & 41.7 \\
Solvents & 2,097 & 206 & 9.8 \\
Gasoline components & 2,098 & 188 & 9.0 \\
Refrigerants & 1,669 & 36 & 2.2 \\
Organic synthesis & 2,098 & 24 & 1.1 \\
Fumigants & 2,102 & 18 & .9 \\
\hline
\end{tabular}

MTBE-use patterns. Detections of MTBE were about five times more likely in areas where MTBE is or has been used in gasoline at greater than 5 percent by volume as part of the oxygenated or reformulated (OXY/RFG) fuels program. Thirty-four other VOCs also were detected at or above $1.0 \mu \mathrm{g} / \mathrm{L}$, but all were detected in less than 1 percent of CWSs.

\section{Concentrations of VOCs}

Concentrations of VOCs in drinkingwater samples ranged from $0.01 \mu \mathrm{g} / \mathrm{L}$ for ethylene dibromide and dibromochloropropane to $930 \mu \mathrm{g} / \mathrm{L}$ for trichloroethene. Of the 2,110 randomly selected CWSs, 6 percent had one or more samples with one or more VOCs with a concentration above the MCL, Health
Advisory (HA), or Drinking-Water Advisory (DWA) (table 2). Concentrations of total THMs at or above $100 \mu \mathrm{g} / \mathrm{L}$ in $46 \mathrm{CWSs}$ were the most common cause for exceeding the MCL (table 2), but concentrations of the solvents tetrachloroethene and trichloroethene at or above $5 \mu \mathrm{g} / \mathrm{L}$ also were reported in more than 1 percent of CWSs.

\section{Distribution of VOCs}

The frequency of detection of any VOC at or above $1.0 \mu \mathrm{g} / \mathrm{L}$ in one or more samples from CWSs varied considerably from State to State. Every State had a detection frequency greater than zero with a range from 22 to 68 percent. The highest detection frequencies occurred in States with high population densities and extensive urban development. The lowest VOC detection frequencies occurred in States with substantial rural regions.

Overall, VOCs were detected at or above $1.0 \mu \mathrm{g} / \mathrm{L}$ three times more frequently in drinking water from systems that are supplied by surface-water sources, or both surface- and ground-water sources, than in systems that are supplied exclusively by ground water. The detections of VOCs also were more frequent in very large and large systems (serving $>3,300$ people) compared to medium and small systems (serving $\leq 3,300$ people). The detection frequency of any VOC in very large systems supplied partly by surface water was driven by the frequent occurrence of THMs. Other VOCs also were detected more frequently in drinking water from the larger systems than in drinking water from smaller systems.
Figure 2. Frequency of detection of volatile organic compounds at concentrations equal to or exceeding 1.0 micrograms per liter in drinking water from randomly selected community water systems (CWSs) in the study area for 20 volatile organic compounds with detection frequencies greater than 1 percent. 
Table 2. Volatile organic compounds that equaled or exceeded regulated or recommended maximum concentrations in drinking water from randomly selected community water systems in the study area, 1993-98

$[\mu \mathrm{g} / \mathrm{L}$, micrograms per liter; MCL, Maximum Contaminant Level; HA, Health Advisory; DWA, Drinking-Water Advisory; CWSs, community water systems

\begin{tabular}{|c|c|c|c|}
\hline \multirow{2}{*}{ Volatile organic compound } & \multicolumn{2}{|c|}{$\begin{array}{l}\text { Drinking-water regulation or } \\
\text { recommended maximum concentration }\end{array}$} & \multirow{2}{*}{$\begin{array}{l}\text { Number of CWSs } \\
\text { reporting concentrations } \\
\text { that equaled or } \\
\text { exceeded value }\end{array}$} \\
\hline & Value, in $\mu g / L$ & Type & \\
\hline Total trihalomethanes & 100 & MCL & 46 \\
\hline Tetrachloroethene & 5 & MCL & 32 \\
\hline Trichloroethene & 5 & MCL & 25 \\
\hline Chloromethane & 3 & HA & 11 \\
\hline Methyl tert-butyl ether & 20 & DWA (lower limit) & 10 \\
\hline Dichloromethane & 5 & MCL & 8 \\
\hline 1,1-Dichloroethene & 7 & MCL & 6 \\
\hline 1,2-Dibromoethane & 0.05 & MCL & 5 \\
\hline Chloroethene & 2 & MCL & 4 \\
\hline Dibromochloropropane & 0.2 & MCL & 3 \\
\hline 1,2-Dichloropropane & 5 & MCL & 3 \\
\hline Benzene & 5 & MCL & 2 \\
\hline 1,2-Dichloroethane & 5 & MCL & 2 \\
\hline cis-1,2-Dichloroethene & 70 & MCL & 2 \\
\hline 1,1,2,3,4,4-Hexachloro-1,3-butadiene & 1 & HA & 1 \\
\hline Tetrachloromethane & 5 & MCL & 1 \\
\hline
\end{tabular}

\section{Conclusions and Implications}

The detection of VOCs at or above $1.0 \mu \mathrm{g} / \mathrm{L}$ in water supplied by CWSs was fairly common. The frequent detection of THMs as a group and as individual compounds is not surprising considering that many CWSs use chlorination for disinfection of drinking water. However, other anthropogenic or natural sources could be responsible for at least some of the concentrations of these compounds detected in drinking water. Further work may help to clarify the potential contribution of THMs from other sources and lead to a better understanding of their transport to drinking-water wells. Compounds in groups that are commonly used such as solvents and gasoline components were frequently detected. The frequent detection of MTBE was related to its common use as a fuel oxygenate in the regions. Because some drinking water has been affected by the occurrence of VOCs from various groups, it would be beneficial for purveyors of drinking water to consider strengthening or enhancing plans for protecting source waters from contamination, in addition to treatment, as a means of further enhancing the quality of drinking water. Although only a relatively small percentage of CWSs had one or more samples with a concentration of a VOC above a health standard, some compounds such as total THMs, tetrachloroethene, and trichloroethene exceeded standards fairly frequently. Because health standards or criteria have been exceeded in some drinking water, a better understanding of the sources, transport, and receptors of VOCs that exceed these values would help in developing plans for better protecting source waters from contamination.

\section{Acknowledgments}

The authors acknowledge the help and cooperation provided by State and local health and environmental agencies in the 12 States, without which this study could not have been completed. This study was done in cooperation with the U.S. Environmental Protection Agency.

\section{References Cited}

Delzer, G.C., Zogorski. J.S., Lopes, T.J., and Bosshart, R.L., 1996, Occurrence of the gasoline oxygenate MTBE and BTEX compounds in urban stormwater in the United States, 1991-95: U.S. Geological Survey Water-Resources Investigations Report 96-4145, 6 p.

Grady, S.J., and Casey, G.D., 1999, A plan for assessing the occurrence and distribution of methyl tert-butyl ether and other volatile organic compounds in drinking water and ambient ground water in the Northeast and Mid-Atlantic regions of the United States: U.S. Geological Survey Open-File Report 99-207, 36 p.
2001, Occurrence and distribution of methyl tert-butyl ether and other volatile organic compounds in drinking water in the Northeast and Mid-Atlantic regions of the United States, 19931998: U.S. Geological Survey WaterResources Investigations Report $00-4228,123 \mathrm{p}$

Lopes, T.J. and Dionne, S.G., 1998, A review of semivolatile and volatile organic compounds in highway runoff and urban stormwater: U.S. Geological Survey Open-File Report 98-409, 67 p.

Lopes, T.J., Fallon, J.D., Rutherford, D.W., and Hiatt, M.H., 2000, Volatile organic compounds in storm water from a parking lot: Journal of Environmental Engineering, v. 126 , no. 12 , p. 1137-1143.

Moran, M.J., Zogorski, J.S., and Squillace, P.J., 1999, MTBE in ground water of the United States-Occurrence, potential sources, and long-range transport, in Water Resources conference, American Water Works Association, Norfolk, Va., Sept. 26-29 [Proceedings]: Denver, Colo., American Water Works Association, CD-ROM.

Squillace, P.J., Moran, M.J., Lapham, W.W., Price, C.V., Clawges, R.M., and Zogorski, J.S., 1999, Volatile organic compounds in untreated ambient groundwater of the United States, 1985 1995: Environmental Science \& Technology, v. 33 , no. 23 , p. 4176-4187.

U.S. Environmental Protection Agency, 1997, Community water system survey, v. 1, overview: Washington, D.C., Office of Water, USEPA 815-R-97001a.

1999, Revisions to the unregulated contaminant monitoring regulation for public water systems; final rule: Washington, D.C., Code of Federal Regulations 40, Parts 9, 141 and 142, p. 50556-50620

2000, Drinking water standards and health advisories: Washington, D.C., Office of Water, USEPA 822-B-00-001, $12 \mathrm{p}$.

Westrick, J.J., Mello, J.W., and Thomas, R.F., 1984, The groundwater supply survey: Journal of the American Water Works Association, v. 76, p. 52-59.

Zogorski, J.S., Delzer, G.C., Bender, D.A., Squillace, P.J., Lopes, T.J., Baehr, A.L., Stackelberg, P.A., Landmeyer, J.E., Boughton, C.J., Lico, M.S., Pankow, J.F., Johnson, R.L., and Thomson, N.R., 1998, MTBE-Summary of findings and research by the U.S. Geological Survey, in Annual Conference of the American Water Works AssociationWater Quality, June 21-25, 1998, Dallas, Tex., [Proceedings]: Denver, Colo., American Water Works Association, p. 287-309. 